\title{
Educational Status and Opinions of Voters Regarding the Social Environment and New Media Tools
}

\author{
Cüneyt Kurtulan ${ }^{1^{*}}$, Esra Aydın Kılıç ${ }^{1}$ \\ ${ }^{1}$ European University of Lefke, N. CYPRUS
}

Received 3 May 2017 - Revised 5 September 2017 • Accepted 7 October 2017

\begin{abstract}
This study was conducted to reveal the opinions of voters regarding the social environment and new media tools with respect to their educational status. In the survey, it was aimed to reveal the factors that constitute the elements of the social environment and new media tools by taking into account the educational situation of voters, which are preliminary. For this purpose, a questionnaire was applied to 440 persons and interviewed in 5 provinces of the Northern part of Cyprus, which were determined by non-probability sampling method. When the research findings were evaluated, it was determined that the graduates of secondary schools are the mostly affected group by social environment during the campaigns. In addition, it was determined that 'new media tools mostly affected graduate/doctoral graduates while voting decision was being.
\end{abstract}

Keywords: political communication, voting decision, education, social environment, new media

\section{INTRODUCTION}

In democratic countries voting periods are big race processes in which candidates and parties try to win the votes of voters. Candidates and parties wish to gain power during this period have tried many ways to convey their commitments and policies to electors. They are located in a wide variety of venues ranging from coffee meetings to large-scale rallies, televised discussion programs, advertisements, newspaper advertisements, flyers, flags and posters. The election process can be viewed as a process by which citizens consider many influences on candidates and parties, and many factors can determine the individual's final decisions. Which of these elements is the forerunner is the question that is being raised by field researchers as well as party / candidates and campaign executives who are candidates for governance. Because voting will determine the outcome of the election at the same time will determine the future of the party and candidates. This critical decision forces parties and candidates to seek different ways of describing themselves. In this regard, the social media's ability to reach the masses in a short period of time and mobilize the masses has also attracted the attention of the political party and campaigners. Parties and candidates are trying to be effective in voting voters' voting campaign through internet. Although it is tried to be effective in the voting decision of the electorate by using the possibilities of the technology, it is thought that it may be clear that the voters' influence due to their personal relations, especially during the election periods. These factors, which play a role in voters' voting decisions, have a number of variables that push them back to the foreground. Among these factors, which are called demographic variables, education has been the focus of attention in recent years not only on the political election decision but also on all the researches about the election of the individuals. In studies, the view that the individual moves more independently and rationally in his decisions as the educational status increases is dominant. In the survey, it is aimed to determine the role of the family, friends and colleagues, social media and the campaigns carried out over the internet in the voting decisions of the individuals according to their educational status. For this purpose, it is aimed to determine which of the "New media" tools and the "social environment" tools, which are thought to play a role in voting decision of the TRNC with the help of a scale tested with validity and reliability analyzes, are the forerunners. In the survey, a questionnaire was applied to 440 people interviewed in Nicosia, Famagusta, Kyrenia, Morphou and İskele districts of TRNC through non-probable sampling method. The questionnaire consists of "demographic information" about 


\section{Contribution of this paper to the literature}

- When the research findings were evaluated, it was determined that the graduates of secondary schools are the mostly affected group by social environment during the campaigns.

- It will be beneficial for political parties to take into consideration the voters' social environment while deciding on their vote.

- When the political campaign is aims to gain votes from crowd of young, it will bring more possibility of power for political campaigns to announce their work from new media.

voters, opinions of voters about "New media Tools" and "Social Environment" sections. The reliability of the questionnaire was obtained by calculating the internal consistency coefficient "Cronbach Alpha". Responses with Likert-type cues were scored, factor analysis was not included in the analyzes with factor load value less than 0.40 . In the study, t-test was applied to determine the differences depending on gender, marital status and nationality variables. One-way ANOVA was used to determine the differences depending on age, occupational status and district variables, and the groups from which the difference originated were determined by the Tukey test. The Mann-Whitney $U$ test was used to compare two groups independent of the non-parametric tests and the KruskalWallis $\mathrm{H}$ test was used to compare the two groups independently. When the research results are evaluated; it is seen that voters between 28-37 age group are more affected by new media tools than other age groups. It has also been found that New media tools are more effective than single-minded voters on voting decisions. Additionally, it was found out that opinion leaders were most influenced by married voters on voting decisions of voters.

\section{Political Communication}

In today's world, studies on political communication are being carried out in many sciences. Many researchers from different fields have gone to researches on political communication and have studied about this field. All these different fields are trying to define the concept of political communication in their own branches (Tokgöz, 2008) .Political communication is "a shift of political news from a transmitter to a receiver, with the intention of sending the receiver in a certain direction so as not to take another form for granted" Windellesman, 1966: 17). This process is known as communication activities, especially in terms of communication activities for politicians in the process of election. In fact, political communication does not take place as activities carried out in electoral circles. Political communication is mainly about how politics is to be carried out or how communication is carried out, how it shapes and presents it. Political communication is an indispensable part of the party or actors who want to come to power. Thinkers such as Marx, Durkheim and Pareto regard political power as "the means by which a group or class dominates over other groups and classes" (KING, 1986: 141-143). Political communication, driven by political systems, should be able to reflect social values. The transfer of social values should be of a quality that political parties and candidates can take power (Esston (D.) Varieties of Political (Theory, Englcwood F. CHAZEL, Socologie Politi'ueue, C. I, p.22.) In almost every aspect of our everyday life (J Blumer and D Kavanagah, 2010: 209). "Political communication is a process in which certain ideological goals and political policies of political actors are divided into certain groups, masses, to use the various types of communication and techniques to make them accepted into the countries or the blocs and transform them into action when necessary "(Aziz, 2013: 3).

In the process of political communication, it is essential that parties or candidates announce their ideologies, their promises, or the features that distinguish them from their opponents in order to be able to collect votes. The strong communication link with voters will speed up the process of persuasion, ensuring that the efforts shown are returned to the party or candidates as votes. The elements that constitute the social environment are crucial for the candidates in establishing this bond, that is, in delivering messages correctly, quickly and sincerely. The election work carried out through these elements is leading the way for better communication between the candidates and the voters in the political communication process. Researchers who are interested in political communication emphasize that this field can only be understood in the same way that media organizations act independently of their social environment and are impartial (Habermas, 2006: 411).

The passion of political thought, modern politics and a democratic electoral system can only be achieved through proper political communication studies (Amme İdaresi Dergisi, Volume 48 Number 2 p.5).

\section{Political Communication Persuasion in Voting Decision of Voters}

Political campaigns aim to create a persuasive force on voters, especially in the electoral process. The development of expected behaviors in voters depends on their ability to be convinced by the right communication methods and tools. Political parties and candidates aim at voting in favor of themselves by persuading voters (Nimmo, 2001: 42). Persuasion is the process of changing the attitudes and behaviors of an individual or a group in 
the desired direction (Luecke, 2007: 70). In this process, it is trying to establish a systematic relationship with voters and to reveal the desired change in line with the aims of the source (Yüksel, A. H. 2005: 4).

Luecke (2007: 71-108) says that persuasion takes place through four elements. They are expressed as "belief, listening comprehension, sound argument and effective communication". Luecke notes that there are six factors that initiate the persuasion process. These factors are; "Benchmarking, enjoyment, reciprocity, social proof, commitment, consistency and authority." Persuasion makes any subject or person more plausible by influencing the person's knowledge, ideas and emotions. For this reason, one of the most important points to be considered in the persuasion process is how to address the feelings or approaches of the other side.

Political campaigns are used to persuade voters to support certain candidates and parties during the election process. In this process, political actors convey the messages that they will use to persuade voters through mass media. Political persuasion; (Çobanoğlu, 2007: 167), is the previously planned, purposeful and intentional communication and messaging techniques to create a preference and behavioral change in the desired direction on the electorate.

In the process of political communication, it is essential that parties or candidates announce their ideologies, their promises, or the features that distinguish them from their opponents in order to be able to collect votes. The strong communication link with voters will speed up the process of persuasion, ensuring that the efforts shown are returned to the party or candidates as votes. The elements that constitute the social environment are crucial for the candidates in establishing this bond, that is, in delivering messages correctly, quickly and sincerely. The election work carried out through these elements is leading the way for better communication between the candidates and the voters in the political communication process. Researchers, who are interested in political communication emphasize that this field can only be understood in the same way that media organizations act independently of their social environment and are impartial (Habermas, 2006: 411).

The passion of political thought, modern politics and a democratic electoral system can only be achieved through proper political communication studies.

\section{The role of education in the voting decision of voters}

Individuals, who start to socialize in the core family that they are born earn their first acquirement of life in these settings. However, when the individual becomes a part of society, only the family environment is not enough. As individuals grow, they need to be trained to make sense of the events surrounding them and to be useful individuals in collecting. Individuals who are educated are becoming social individuals who can make their own decisions, transfer ideas and opinions to other individuals, pass on ideas that are imposed by others, As well as being in different fields, educated individuals are able to express opinions in the field of political communication instead of directly conveying the messages sent by the party or actors in order to create a convincing power. (Ford, P. 1986: 1-12).

Increased levels of education of voters are accompanied by changes in voter participation. In the research conducted, the level of education that the individual has throughout his / her life ensures that he / she makes longterm and healthier decisions in political life. A study conducted in 1952-2004 in the United States to determine the role played by elected voters on voting decisions in the United States found a strong positive relationship between the level of education and voting prospects of individuals (Burden, 2009: 541).

Burden says that various attitudes and demographic variables affect the probability of voting, the most effective being education (Burden, 2009: 542).

A lot of research has been done by researchers that there is a strong relationship between life-long education and political participation. (E.g., Miller, 1992, Miller and Shanks, 1996, Rosenstone and Hansen, 1993, Verba et al., 1995). The relationship between the education system and the socio-economic environment of the individual is very important in voter voting decision and in increasing political participation (Lewis-Beck et al., 2008, 102).

Researchers say that education is a tool that influences voter participation levels (Kam and Palmer, 2008: 612631). At the same time, many studies show that absolute education levels actually affect voting. Dee (2004), Milligan (2004) and Sondheimer (2006)

Education gives individuals skills to understand political life. (Delli Carpini and Keeter, 1996). Education sets the fate of the election for voters by removing the obstacles that cause the other vote in the decision phase (Highton, 2004, Powell, 1986, Timpone, 1998, Verba et al., 1995, Wolfinger and Rosenstone, 1980).

\section{Social media as an election tool}

The starting point of the press, the media, behind the technological developments in different forms spread to a wide and scattered mass groups. Thanks to these technological developments, the exchange of media has become inevitable in our world. Mass media continued to be a one-way relationship until the year 2000. Then social 
networks, which we have characterized as new media, along with media producers and users, (Mandiberg, 2012, p.1) The development of communication technologies and the widespread use of the Internet have made it possible to conduct political debate through social media and to put forward different opinions (Dahlgren, 2005: 148). If it defines social media, according to Blossom, social media defines it as "highly scalable and accessible communication technologies or techniques that make it possible for each individual to easily influence other groups of individuals" (Akar, 2010, p.1 7) The widespread use of social media and its frequent use by large masses allows these networks to be used in many different areas. Social media, which has a wide range of uses, from the use of enterprises to the introduction of products to the discussion of political issues in the country and the conduct of election work, is also frequently used, especially today, in political matters.

Political studies carried out through social media are increasing day by day. Political parties and candidates carry out their political campaigns on many social networks such as Facebook, Twitter, Youtube, Instagram and announce their voices to voters through these means. The first Internet-based political communication work we can call "online politics" or "political chat" is the United States of America (Douglas Kellner, 2011: 45). President of the United States Barack Obama, who runs the so-called "media show" election campaign through social media, has won the title of being the first president to win elections by using social media and social networks (Ak1nc1 Vural and Bat, 2009, p 2758). Obama is more influential than McCaine, his opponent by running his political campaigns through social networks on the axis of information and communication technologies (Borins, 2011: 86). In another presidential race through social media, social networks have helped Roh Moo Hyun win the South Korean presidency. "The Washington Post" corner writer David Broder states that in China, students live in websites that have emerged in an abundance that the government itself cannot effectively control as a forum for expressing ideas in China "(Hiebert, 2005: 4). The Social Environment in the Resolution of the Speakers

The social environment is a part of the whole that is created by the individual's family, the environment they live in, or the factors that they live with. It is a neighborhood, a village or a city where the person lived. The social environment helps the individual to decide on many issues. Many other factors, such as social environments, political communication and power relations, buried in the social circle play a role in the decisions of individuals (Barnett and Casper, 2001: 465). Social environment "is a real field that defines the limit of social structure. The social environment separates a social construct from other social constructs. Every social structure has its own social environment. Social structures are separated from each other by the boundaries of their social environment "(Nirun, 1991: 3-18).

The environment that arises from the relations among the institutions (schools, etc.) existing in society constitutes the social environment (Kongar, 1985: 32-34). Mankind is in close contact with its surroundings as well as with people who live under the same roof. The social environment comes from the family, neighborhood, friends, community and other social environment items (social institutions, social groups or social organizations). These social environment items shape the lives of the individual as well as the political process, which is active in making decisions. Voters are influenced not only by messages sent over the mass media, but also by their social relations. This effect consists of family members, community, and other social environment items that people closely associate with.

\section{RESEARCH METHOD}

\section{Selection of Research Area and Respondents}

Nicosia, Famagusta, Kyrenia, Morphou and İskele constitute the universe of the research carried out in the TRNC. In the scope of the research, there are included 18, 40 years old and over 440 people registered in TRNC voting register in the direction of non-probability sample. Nicosia 55.040 registered in the electoral register, Famagusta 45.679 Kyrenia 34.956, Morphou 20.720 and İskele 18.863 are registered. In this direction, the research has been applied to a total of 440 people, including 140 in Nicosia, Famagusta 114, Girne 87, Güzelyurt 51 and 48 in Iskele.

\section{Preparation of Questionnaire Form}

\section{The questionnaire consists of three parts;}

In the first part, there are questions aimed at reaching demographic information about the voters included in the survey. In this respect, there are questions about the district, age, gender, marital status, education status, nationality and occupation status of the voters in the first chapter. 
Table 1. Frequency and Percentage Distributions of Repeated Reporters' Response to New media Tools ( $n=440$ )

\begin{tabular}{|c|c|c|c|c|c|c|c|c|c|c|c|c|}
\hline \multirow{2}{*}{ Statement } & \multicolumn{2}{|c|}{$\begin{array}{l}\text { I strongly } \\
\text { disagree }\end{array}$} & \multicolumn{2}{|c|}{$\begin{array}{l}\text { I do not } \\
\text { agree }\end{array}$} & \multicolumn{2}{|c|}{ undecided } & \multicolumn{2}{|c|}{ I agree } & \multicolumn{2}{|c|}{$\begin{array}{l}\text { Absolutely } \\
\text { I agree }\end{array}$} & \multicolumn{2}{|c|}{ TOTAL } \\
\hline & f & $\%$ & $f$ & $\%$ & $f$ & $\%$ & $f$ & $\%$ & $f$ & $\%$ & $f$ & $\%$ \\
\hline $\begin{array}{l}\text { 1. Political advertisements on the Internet are } \\
\text { effective in voting. }\end{array}$ & 174 & 39.5 & 176 & 40.0 & 38 & 8.6 & 33 & 7.5 & 19 & 4.3 & 440 & 100.0 \\
\hline $\begin{array}{l}\text { 2. Political news on the Internet newspaper is } \\
\text { influential in the decision to vote. }\end{array}$ & 155 & 35.2 & 159 & 36.1 & 47 & 10.7 & 52 & 11.8 & 27 & 6.1 & 440 & 100.0 \\
\hline $\begin{array}{l}\text { 3. Shares involving candidates on Facebook and } \\
\text { Twitter have an impact on voting profits. }\end{array}$ & 136 & 30.9 & 137 & 31.1 & 42 & 9.5 & 79 & 18.0 & 46 & 10.5 & 440 & 100.0 \\
\hline
\end{tabular}

In the second part, 3 sentences were sent to the voters in order to determine their views on the "New media" tools. The following are the statements by which voters participating in the survey will indicate their participation status in this measure:

"Political advertising on the Internet is influential in voting drive", "Political news on the Internet journal is influential in casting vote", "Sharing on candidates on Facebook and Twitter is effective in voting motivations"

In the third chapter, 4 statements were used to measure the opinions of the voters about "Social Network";

"My family's views are influential in my voting motivation.", "My neighborhood's views are influential in voting motivation.", "My friends 'views are influential in voting motivation.", "My colleagues' views are influential in voting motivation."

\section{Evaluation of Data}

The data obtained from the research are collected in the database created by using the statistical package program software and the data are classified and sized by the possibility of performing arithmetic and logical operations provided by this software. Absolute and percentage values of each sentence in the scope of the research were prepared and necessary arithmetic averages were calculated. In the survey, the provinces were examined considering the age, gender, marital status, education status, nationality and occupational status variables.

Percentage values were given in the section "demographic information on voters" included in the research and necessary arithmetic averages were taken.

Measures for expressing opinions in the "New media tools" and "Social environment" sections; I strongly agree (5), agree (4), undecided (3), disagree (2), strongly disagree (1).

\section{Demographic Information for Voters}

According to the distribution in the demographic characteristics of voters, $31.8 \%$ of the people in the survey live in Nicosia, 26.1\% in Famagusta, 19.8\% in Kyrenia, 10.7\% in İskele and 11.6\% in Morphou. 53\% of the participants were women and $47 \%$ were women. When the distribution of participants according to their ages were examined, it was found that $21.6 \%$ of them were $18-27,27.7 \%$ of them were $28-37,20.9 \%$ of them were $38-47$ and $29.8 \%$ of them were 48 years and over. In addition, $61.4 \%$ of the voters included in the survey were single, while $38.4 \%$ were married.

When the distributions of the participants according to educational status are examined, it is seen that $0.9 \%$ is not literate, $2.3 \%$ is literate, $8.0 \%$ is primary school, $11.8 \%$ is middle school, $34.1 \%$ High school, $36.4 \%$ had university degree and $6.6 \%$ had graduate education. $85.0 \%$ of the respondents were T.R.N.C., and $15.0 \%$ are T.R.N.C. and other state citizens. Finally, demographical characteristics of the participants are as follows: $11.8 \%$ are students, $13.2 \%$ are housewives, $19.1 \%$ are civil servants, $10.2 \%$ are workers, $20.9 \%$ U self-employed, $3.4 \%$ businessmen, $7.0 \%$ trades and $14.3 \%$ others.

\section{New media tools}

The results of the New media subtitle are given in Table 1. Opinions of voters about new media tried to be determined with 3 replies "absolutely agree", "agree", "undecided", "do not agree”, "absolutely disagree" answers. Regarding this dimension, it has been determined that the voters' voting decision is most affected by the share of candidates in Facebook and Twitter, and at least in political advertisements on the internet.

"Political ads on the Internet are influential in voting drive." Regarding the Clemis, it is clear that $4.3 \%$ strongly agree, $7.5 \%$ agree, $8.6 \%$ undecided, $40.0 \%$ disagree and $39.5 \%$ strongly disagree.

A survey of voters' responses to their vote showed that $6.1 \%$ strongly agree, $11.8 \%$ agree, $10.7 \%$ undecided, $36.1 \%$ disagree, and finally $35.2 \%$ strongly disagree. 
Table 2. An Analysis of the Variance Between Gender, Marital Status and Nationality Variables and the Sub-Dimensions of Opinions of Voters' Opinions Toward New media tools (t-test)

\begin{tabular}{|c|c|c|c|c|c|c|}
\hline Dimensions / Factors & Variables & Groups & Average $\bar{X}$ & s.d. & $\mathbf{t}$ & $\mathbf{p}$ \\
\hline \multirow{6}{*}{ New media tools } & \multirow{2}{*}{ Sex } & Female & 2.27 & 0.96 & \multirow{2}{*}{0.534} & \multirow{2}{*}{0.594} \\
\hline & & Male & 2.22 & 0.97 & & \\
\hline & \multirow{2}{*}{ Marital Status } & Married & 2.17 & 0.99 & \multirow{2}{*}{2.161} & \multirow{2}{*}{$0.031^{*}$} \\
\hline & & Single & 2.38 & 0.94 & & \\
\hline & \multirow{2}{*}{ Nationality } & T.R.N.C. & 2.24 & 0.95 & \multirow{2}{*}{-0.740} & \multirow{2}{*}{0.460} \\
\hline & & T.R.N.C and Others & 2.33 & 1.05 & & \\
\hline
\end{tabular}

${ }^{*} p<0.05$

When the last sentence of this dimension is examined voters' votes on Facebook and Twitter about voting on candidates are influential in my decision to vote. "Their responses to the climax are as follows. It was determined that $10.5 \%$ were strongly agree, $18.0 \%$ were agree, $9.5 \%$ were undecided, $31.1 \%$ disagree, and $30.9 \%$ strongly disagree.

\section{Opinions of voters towards new media tools by gender}

In the context of Table 2, it was tried to be determined by t-test for the independent samples that the voters' characteristics of new media tools made a difference according to gender in voting decision. There were no significant differences in terms of new media tools determined within the scope of political campaign and mass media by gender $(\mathrm{p}=0.236 ; \mathrm{p}=0.121 ; \mathrm{p}=0.358 ; \mathrm{p}>0.05)$.

\section{Opinions of voters about new media tools according to marital status}

Table 2. Within the scope of the study, it was tried to be determined by making a t-test for the independent samples that the characteristics of the new media tools did not differ according to the marital status of voters in voting decision. In the new media tools determined within the scope of the national campaign and mass media, it was determined to be different. When the difference determined according to marital status variable in the dimension of new media tools is examined, it is seen that single voters $(\bar{X}=2.38)$ are more influenced by internet and media tools than married voters $(\bar{X}=2.17)$. The results of the survey showed that the single voters in the survey were more influenced by the political news on the internet and by voters who were married to Facebook and Twitter about the candidates. The fact that single voters are more influenced by new media tools than by married voters can be attributed to the fact that their responsibilities towards life are less than their marriages.

\section{Opinions of voters towards new media tools according to their nationality}

In the scope of Table 2, it was tried to be determined by t-test for independent samples in which the voters' characteristics of new media tools differ according to their nationality in voting decision. It has been determined that there is no significant difference in the size of new media included in this scale.

\section{Opinions of voters about new media tools according to their educational status}

Table 3 shows the Kruskal-Wallis H Test and the Mann Whitney U Test conducted to compare the educational status of voters and the expressions of internet-social media. These test results were found to have significant differences in terms of educational status according to the educational status of voters on the new media tools. The differences were found to be between primary school graduates $(\bar{X}=94.40)$, middle school $(\bar{X}=160.63)$, high school $(\bar{X}=218.99)$, university $(\bar{X}=252.93)$ and master $/(\bar{X}=216.89)$, high school $(\bar{X}=218.99)$, university $(\bar{X}=252.93)$ and master / doctorate $(\bar{X}=264.38)$, secondary school graduates $(\bar{X}=160.63)$, University $(\bar{X}=252.93)$ and master / doctorate $(\bar{X}=264.38)$, and finally university graduates $(\bar{X}=252.93)$ and master / doctoral graduates $(\bar{X}=264.38)$. According to the determined arithmetic mean, the group that took the most attention when making a decision to vote internet and social media tools was the graduate / doctorate graduates $(\bar{X}=264.38)$ while the least conspicuous group was the literate ones $(\bar{X}=94.40)$. Therefore, it can be said that those with higher educational level are more influenced by new media tools in this sense. 
Table 3. Comparison of Voters' Opinions Toward New media tools and Training Variables (Kruskal-Wallis H Test)

\begin{tabular}{cc}
\hline $\begin{array}{c}\text { Dimensions / Factors } \\
\text { Education Status }\end{array}$ & New Media Tools \\
\hline Not literate $(\mathrm{n} / \bar{X})$ & $4 / 233,38$ \\
\hline Literate $(\mathrm{n} / \bar{X})$ & $10 / 94,40$ \\
\hline Primary school $(\mathrm{n} / \bar{X})$ & $35 / 165,89$ \\
\hline Middle school $(\mathrm{n} / \bar{X})$ & $52 / 160,63$ \\
\hline High school $(\mathrm{n} / \bar{X})$ & $150 / 218,99$ \\
\hline University $(\mathrm{n} / \bar{X})$ & $160 / 252,93$ \\
\hline Master / Doctorate $(\mathrm{n} / \bar{X})$ & $29 / 264,38$ \\
\hline Chi-Square & 42,317 \\
\hline $\mathrm{P}$ & $0,000^{\star}$ \\
\hline & $2-4,5,6,7$ \\
\hline Mann Whitney U Test & $3-5,6,7$ \\
\hline
\end{tabular}

${ }^{*} \mathrm{p}<0,05$ (1: Not literate, 2: Literate, 3: Elementary school, 4: Middle school, 5: High school, 6: University, 7: Master / PhD) 1,2,3,4,5,6,7 The difference is significant.

Table 4. Investigations of Voters' Differences Between Opinions Towards New Media Tools and District Variables (Anova and Tukey Test)

\begin{tabular}{|c|c|c|c|c|c|c|c|}
\hline Variable & Dimensions / Factors & Groups & Avarage. $\bar{X}$ & s.d. & $\mathbf{F}$ & $\mathbf{p}$ & Tukey \\
\hline \multirow{5}{*}{ District } & \multirow{5}{*}{ New media tools } & Nicosia & 2,41 & 0,94 & \multirow{5}{*}{4,844} & \multirow{5}{*}{$0,001^{*}$} & \multirow{5}{*}{$\begin{array}{c}1-2,4 \\
2-1 \\
4-1,5 \\
5-4\end{array}$} \\
\hline & & Famagusta & 2,06 & 0,93 & & & \\
\hline & & Kyrenia & 2,30 & 0,93 & & & \\
\hline & & İskele & 1,87 & 0,71 & & & \\
\hline & & Morphou & 2,49 & 1,20 & & & \\
\hline
\end{tabular}

${ }^{*} \mathrm{p}<0,05$ (1:Nicosia, 2:Famagusta, 3:Kyrenia, 4:Iskele, 5:Morphou) 1, 2, 3, 4, 5 The difference between the groups is significant.

Table 5. Investigation of Voters' Differences Between Opinions Toward New Media Tools and Vocational Variables (Anova and Tukey Test)

\begin{tabular}{|c|c|c|c|c|c|c|c|}
\hline Variable & Dimensions / Factors & Groups & Average $\bar{X}$ & s.d. & $\mathbf{F}$ & $p$ & Tukey \\
\hline & \multirow{8}{*}{ New media tools } & Officer & 2.41 & 0.95 & \multirow{8}{*}{2.500} & \multirow{8}{*}{0.056} & \multirow{8}{*}{--- } \\
\hline & & Worker & 2.12 & 0.82 & & & \\
\hline & & Business man & 2.80 & 1.19 & & & \\
\hline & & Student & 2.44 & 0.87 & & & \\
\hline & & Housewife & 2.01 & 0.86 & & & \\
\hline & & Artisan & 1.96 & 0.98 & & & \\
\hline & & Self-employed & 2.30 & 0.94 & & & \\
\hline & & Other & 2.14 & 1.13 & & & \\
\hline
\end{tabular}

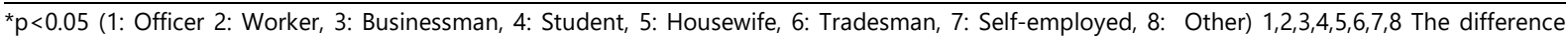
between the other groups is significant.

\section{Opinions of voters towards new media tools according to provinces living}

A comparison of the voters' voting decisions regarding the new media tools was made according to the districts (Anova and Tukey Test) and the results of the one-way analysis of variance and the Tukey test results for the source of the difference are shown in Table 4. According to the results, it is determined that there are significant differences in the dimension of internet-social media. At this point, when the differences between the districts in the subdimension of new media tools are examined, it is determined that the voters who live in the provinces of Famagusta and Iskele have similar views while the voters living in Kyrenia and Morphou districts have similar opinions with those living in other districts.

\section{Opinions of voters toward new media tools according to occupations}

The results presented in Table 5 focus on the examination of the voters' differences between the opinions of the voters on the new media tools and the profession and the results of the one-way analysis of variance and the results of the Tukey test for the source of difference. There were no significant differences among the voters according to the opinion of the voters regarding the new media tools $(p=0.004, p<0.05)$. 
Table 6. An Examination of the Difference Between the Sub-Dimensions and the Age Variables in the Opinions of Voters' Opinions Toward New Media Tools (Anova and Tukey Test)

\begin{tabular}{|c|c|c|c|c|c|c|c|}
\hline Variable & Dimensions/Factors & Groups & Average. $\bar{X}$ & s.d. & $\mathbf{F}$ & $\mathbf{p}$ & Tukey \\
\hline & \multirow{4}{*}{ New media tools } & $18-27$ & 2.38 & 0.94 & \multirow{4}{*}{9.184} & \multirow{4}{*}{$0.000^{*}$} & $1-4$ \\
\hline & & $28-37$ & 2.47 & 1.03 & & & $2-4$ \\
\hline & & $38-47$ & 2.33 & 0.95 & & & $3-4$ \\
\hline & & $48>$ & 1.90 & 0.84 & & & $4-1,2,3$ \\
\hline
\end{tabular}

$* \mathrm{p}<0,05(1: 18-27,2: 28-37,3: 38-47,4: 48>)$ 1, 2, 3, 4 The difference between the groups is significant.

Table 7. Frequency and Percentage Distributions of Voters' Responses to Social Environment $(n=440)$

\begin{tabular}{|c|c|c|c|c|c|c|c|c|c|c|c|}
\hline \multirow[t]{2}{*}{ Statements } & \multicolumn{2}{|c|}{$\begin{array}{c}\text { I } \\
\text { strongly } \\
\text { disagree }\end{array}$} & \multicolumn{2}{|c|}{$\begin{array}{c}\text { I } \\
\text { disagree }\end{array}$} & \multicolumn{2}{|c|}{ Undecided } & $\begin{array}{c}\text { I } \\
\text { Agree }\end{array}$ & \multicolumn{2}{|c|}{$\begin{array}{c}\text { I } \\
\text { Strongly } \\
\text { agree }\end{array}$} & \multicolumn{2}{|c|}{ TOTAL } \\
\hline & $\mathbf{f}$ & $\%$ & $\mathbf{f}$ & $\%$ & $\mathbf{f}$ & $\%$ & f $\%$ & $\mathbf{f}$ & $\%$ & $\mathbf{f}$ & $\%$ \\
\hline 1. The views of the family are influential in voting casting. & 20 & 4.5 & 58 & 13.2 & 26 & 5.9 & 7216.4 & 264 & 60.0 & 440 & 100.0 \\
\hline 2. The opinions of my neighbors are influential in voting drive. & 93 & 21.1 & 128 & 29.1 & 43 & 9.8 & 6514.8 & 111 & 25.2 & 440 & 100.0 \\
\hline 3. The views of my friends are effective in voting. & 53 & 12.0 & 105 & 23.9 & 46 & 10.5 & 9220.9 & 144 & 32.7 & 440 & 100.0 \\
\hline 4. The opinions of my colleagues are effective in voting. & 81 & 18.4 & 133 & 30.2 & 48 & 10.9 & 7817.7 & 100 & 22.7 & 440 & 100.0 \\
\hline
\end{tabular}

\section{Opinions of voters towards new media tools by age}

An examination of the voters' opinions on new media tools presented in Table 6 and the difference between age variance was tested by one-way analysis of variance and Tukey test for the source of difference. According to the findings, it can be said that significant differences are determined according to the new media tools. It has been determined that there is a difference between those who are in the 48-year age group $(\bar{X}=1.90)$ and all other age groups in the new media tools. For this sub-dimension, $48 \%$ of the age group may be affected by the lowest rate of voting on the new media media because they do not use these tools as young as the older ones. The age group of voters who are most affected by the New media tools is $28-37(\bar{X}=2.47)$. Therefore, this age group can be associated with being more active on the internet and being influenced by these channels without voting in the elections.

\section{Social environment}

Voters' attitudes to participate in discussions about the social environment have been tried to be evaluated with the answers "strongly agree", "agree", "undecided", "disagree", "strongly disagree"

It was determined that $60.0 \%$ strongly agree with this opinion, $16.4 \%$ agree, $5.9 \%$ undecided, $13.2 \%$ disagree, and $4.5 \%$ absolutely disagree when voters' opinion on their vote is influential

The voters' opinions of my neighbors are influential in my decision to cast votes.

It was determined that $25.2 \%$ of the participants were absolutely, $14.8 \%$ were in the participation, $9.8 \%$ were unstable, $29.1 \%$ did not participate and $21.1 \%$ did not participate.

"My friends' views are influential in voting." Regarding the vote, it was seen that $32.7 \%$ of voters strongly agree, $20.9 \%$ participated, $10.5 \%$ undecided, $23.9 \%$ disagree and $12.0 \%$ absolutely disagree.

"My colleagues' views are influential in my decision to vote." With regard to voting, voters have stated that they do not agree with it at the rate of $30.2 \%$. As for the other percentages, $22.7 \%$ stated that they strongly agree, $17.7 \%$ agree, $10.9 \%$ undecided and $18.4 \%$ absolutely disagree.

Table 7 gives the frequency and percentage distributions of opinion about the opinion leaders of the voters. Within these expressions, the expression "family views are influential in voting decision" $(\bar{X}=4.14)$ has the highest overall average value and the highest general average is "friends' views are influential in voting decision" $(\bar{X}=$ 3.38) The opinions of my colleagues are influenced by my voting motivation. " $(\bar{X}=2.96)$ and" the opinions of my neighbors are influential in voting motivation " $(\bar{X}=2.93)$. Within the scope of these results, it can be said that the voters attach importance to the opinions of the family at the highest level in the opinion leaders' sub-dimension, but they do not consider the opinions of the neighbors very much. 
Table 8. Survey of Social Environment Dimension of Voters and Gender, Marital Status and Nationality Variables (t-test)

\begin{tabular}{|c|c|c|c|c|c|c|}
\hline Dimensions / Factors & Variables & Groups & Average $\bar{X}$ & s.d. & $\mathbf{t}$ & $\mathbf{p}$ \\
\hline \multirow{6}{*}{ Social Environment } & \multirow{2}{*}{ Sex } & Female & 3.33 & 1.13 & \multirow{2}{*}{-0.376} & \multirow{2}{*}{0.707} \\
\hline & & Male & 3.37 & 1.15 & & \\
\hline & \multirow{2}{*}{ Martial Status } & Married & 3.46 & 1.16 & \multirow{2}{*}{-2.603} & \multirow{2}{*}{$0.010^{*}$} \\
\hline & & Single & 3.17 & 1.08 & & \\
\hline & \multirow{2}{*}{ Nationality } & T.R.N.C & 3.33 & 1.16 & \multirow{2}{*}{-1.136} & \multirow{2}{*}{0.257} \\
\hline & & T.R.N.C and Others & 3.50 & 1.02 & & \\
\hline
\end{tabular}

Table 9. An Examination of the Difference Between Voters' Social Dimension and District Variance (Anova and Tukey Test)

\begin{tabular}{|c|c|c|c|c|c|c|c|}
\hline Variable & Dimensions/Factors & Groups & Average $\bar{X}$ & s.d. & $\mathbf{F}$ & $\mathbf{p}$ & Tukey \\
\hline \multirow{5}{*}{ District } & \multirow{5}{*}{ Social Environment } & Nicosia & 3.47 & 1.16 & \multirow{5}{*}{2.967} & \multirow{5}{*}{$0.019^{*}$} & $1-5$ \\
\hline & & Famagusta & 3.16 & 1.14 & & & $2-4$ \\
\hline & & Kyrenia & 3.45 & 1.06 & & & $3-5$ \\
\hline & & İskele & 3.62 & 1.17 & & & $4-2,5$ \\
\hline & & Morphou & 3.03 & 1.09 & & & $5-1,3,4$ \\
\hline
\end{tabular}

${ }^{*} \mathrm{p}<0.05$ (1:Nicosia, 2:Famagusta, 3:Kyrenia, 4:İskele, 5:Morphou) 1, 2, 3, 4, 5 The difference between the groups is significant.

Table 10. An Examination of the Difference Between Voters' Social Dimension and Age Variance (Anova and Tukey Test)

\begin{tabular}{|c|c|c|c|c|c|c|c|}
\hline Variable & Dimensions/Factors & Groups & Average $\bar{X}$ & s.d. & $\mathbf{F}$ & $\mathbf{p}$ & Tukey \\
\hline \multirow{4}{*}{ Age } & \multirow{4}{*}{ Social Environment } & $18-27$ & 3.03 & 1.02 & \multirow{4}{*}{3.487} & \multirow{4}{*}{$0.016^{*}$} & \multirow{4}{*}{$\begin{array}{c}1-3,4 \\
3-1 \\
4-1\end{array}$} \\
\hline & & $28-37$ & 3.37 & 1.13 & & & \\
\hline & & $38-47$ & 3.50 & 1.15 & & & \\
\hline & & $48>$ & 3.46 & 1.19 & & & \\
\hline
\end{tabular}

${ }^{*} p<0.05(1: 18-27,2: 28-37,3: 38-47,4: 48>)$ 1, 2, 3, 4 The difference between the groups is significant.

The analysis of the "social environment" dimension and the difference between gender, marital status and nationality variables was analyzed by t-test for independent samples. A significant difference was found between the dimension and marital status $(p=0.010 ; p=0.707 ; p=0.257 ; p>0.05)$, although there was no significant difference between the dimensions of opinion leaders and gender and nationality variables $<0.05$ ). Therefore, it was determined that those who married were more conscious of opinion leaders than those who were married. This can be related to the fact that married voters have more responsibilities in life than single voters and therefore take more into account the promises of opinion leaders.

An examination of the differences between the voters' views towards "Social Environment" and the district change was made by one way variance analysis and Tukey test for the source of difference. When the results were evaluated, differences were determined among the groups in the district variable in terms of opinion leaders. The differences were determined between Nicosia and Morphou districts, between Famagusta and Iskele districts, between Kyrenia and Morphou districts, between Iskele districts with Famagusta and Morphou districts, and between Morphou and Famagusta. In this sense, opinion leaders influence voter views to a significant extent in some provinces, but at the highest level in the province of Iskele, the voters who live in the province of Morphou are the least affected.

An examination of the differences between voters' views towards "Social Environment" and age variation was also made by one way variance analysis and Tukey test for the source of difference. Significant differences were found between opinion leaders sub-dimension and age group for the determined results. Significant differences according to age groups in opinion leaders subscale were determined in the 18-27 age group and 38-47 and 48> age groups. This result shows that voters of age 38 and older are more influenced by opinion leaders than by other age groups. Opinion leaders did not play an important role in voting for young people aged 18-27. 
Table 11. Comparison of Social Environment Dimension and Educational Status Variable of Voters (Kruskal-Wallis H Test)

\begin{tabular}{cc}
\hline $\begin{array}{c}\text { Dimensions/Factors } \\
\text { Educational Status }\end{array}$ & Social Environment \\
\hline Not-literate $(\mathrm{n} / \bar{X})$ & $4 / 121.25$ \\
\hline Literate $(\mathrm{n} / \bar{X})$ & $10 / 230.75$ \\
\hline Primary School $(\mathrm{n} / \bar{X})$ & $35 / 233.87$ \\
\hline Secondary School $(\mathrm{n} / \bar{X})$ & $52 / 249.10$ \\
\hline High School $(\mathrm{n} / \bar{X})$ & $150 / 224.81$ \\
\hline University $(\mathrm{n} / \bar{X})$ & $160 / 218.26$ \\
\hline Master/Doctorate $(\mathrm{n} / \bar{X})$ & $29 / 153.33$ \\
\hline Chi-Square & 13.950 \\
\hline $\mathrm{P}$ & $0.030^{*}$ \\
\hline & $1-4$ \\
& $3-7$ \\
\hline Mann Whitney U Test & $4-1,7$ \\
& $5-7$ \\
\hline & $6-7$ \\
\hline
\end{tabular}

${ }^{*} \mathrm{p}<0.05$ (1: Not literate, 2: Literate, 3: Elementary school, 4: Middle school, 5: High school, 6: University, 7: Master / Doctorate) 1, 2, 3, 4, 5, 6, 7 The difference between the groups is significant.

Table 12. Examination of the Difference Between Voters' Social Dimension and Vocational Variance (Anova and Tukey Test)

\begin{tabular}{|c|c|c|c|c|c|c|c|}
\hline Variable & Dimensions/Factors & Groups & Average. $\bar{X}$ & s.d. & $\mathbf{F}$ & $\mathbf{P}$ & Tukey \\
\hline \multirow{8}{*}{ Job } & \multirow{8}{*}{ Social Environment } & Officer & 3.37 & 1.13 & \multirow{8}{*}{1.458} & \multirow{8}{*}{0.181} & \multirow{8}{*}{---} \\
\hline & & Worker & 3.20 & 1.14 & & & \\
\hline & & Business man & 3.65 & 1.15 & & & \\
\hline & & Student & 3.11 & 0.95 & & & \\
\hline & & Housewife & 3.51 & 1.12 & & & \\
\hline & & Artisan & 3.35 & 1.15 & & & \\
\hline & & Self-employment & 3.55 & 1.16 & & & \\
\hline & & Other & 3.13 & 1.24 & & & \\
\hline
\end{tabular}

${ }^{*} \mathrm{p}<0.05$ (1: Officer 2: Worker, 3: Businessman, 4: Student, 5: Housewife, 6: Tradesman, 7: Self-employed, 8: Other) The difference between the groups is significant.

Significant differences were determined according to the educational status of the voters when the voters' education status and the expression of "Social Environment" were examined. Differences determined by social environment dimension and the educational status of voters are found between non-illiterate and junior high school graduates, between primary school graduates and master / doctoral graduates, between middle school graduates and non-literate and master / doctoral graduates, Bachelor / Ph.D. among the graduates, between the university graduates and the graduate / doctoral graduates, and therefore the graduate / doctoral degree among primary, secondary, high school and university graduates. The role of opinion leaders on graduate / doctoral graduates is the lowest in voting decisions of voters for the opinion leaders out of the determined arithmetic averages. The role of opinion leaders has been shown to be slightly higher in other educational situations, and even higher in secondary school graduates.

The results of the one-way analysis of variance and the results of the Tukey test for the source of diversity are used to examine the differences between the voters' views on the "social environment" and the profession. According to the findings in the table, no significant difference was found between the opinion leaders subdimension and the occupational groups.

In Table 13, Pearson correlation analysis was tried to examine the relationship between voters' new media tools and social environment dimensions. In this context, the level of the relationship between the variables is "very weak" if the Pearson correlation coefficient is below 0.19, "weak" for 0.20-0.39, "medium" for 0.40-0.59, (Ural and Kilic, 2005: 220) for "strong" for -0.79 and "very strong" for $0.80-1.00$. In this point, the correlation coefficients calculated in Table 13 were examined and the following evaluations were made:

It has been found that there is a positive correlation between the New media tools and opinion leaders subdimensions $(r=0.212)$. 
Table 13. Investigation of the Relationship Between Voters' New media and Social Environment Dimensions (Correlation Analysis)

\begin{tabular}{|c|c|c|c|c|c|c|c|}
\hline & & & & $\begin{array}{l}\text { New media } \\
\text { Tools }\end{array}$ & & $\begin{array}{l}\text { Social } \\
\text { vironm }\end{array}$ & \\
\hline \multirow{2}{*}{ New media tools } & $\mathrm{R}$ & 0.634 & 0.582 & \multirow{2}{*}{1} & 0.355 & 0.212 & 0.353 \\
\hline & $p$ & $0.000^{* *}$ & $0.000^{* *}$ & & $0.000^{* *}$ & $0.000^{* *}$ & $0.000^{* *}$ \\
\hline \multirow{2}{*}{ Social Environment } & $r$ & 0.190 & 0.140 & 0.212 & 0.345 & \multirow{2}{*}{1} & 0.610 \\
\hline & $\mathrm{p}$ & $0.000^{* *}$ & $0.000^{* *}$ & $0.000^{* *}$ & $0.000^{* *}$ & & $0.000^{* *}$ \\
\hline
\end{tabular}

\section{RESULTS}

In the survey, the role of the social environment and the mass media in the voting decisions of voters was based on the demographic variables of voters. In this part of the study, the results of the analysis of the voters' views on the social environment and the mass media were analyzed firstly on the basis of sub-titles, on the basis of the educational status variable, then on the dimensions in general. This section also included Pearson Correlation analysis results to determine the relationship between voters' views of the social environment and the mass media.

Significant differences were found in the New media tools according to the educational status of voters. The differences are determined by literacy, secondary school, high school, university and master / doctorate, primary school graduates with high school, university and master / doctorate, secondary school graduates with high school, university and master degree / doctorate, / Doctoral graduates. According to the determined arithmetic mean, according to the education level, the group that is in the preliminary in the voting decisions of internet and social media tools are graduate / doctoral graduates while the least conspicuous group is the literate ones. It was found that voters were at the highest level $(10.5 \%)$ participating in the statement "voting on Facebook and Twitter is effective in voting drive". It is interesting to note that the results are influenced by political advertisements on the internet and content on social networking sites such as Twitter and Facebook, which are not so striking as these results can be explained by the fact that these individuals cannot use internet tools, while those who are said to be able to rationally make their own decisions in their studies. In this sense, the results of the research can be explained by the fact that those with higher education level are more open to the Internet because of the more use of the internet and the mentioned social platforms. At this point, it is suggested that the questions such as who is the source of the content and the content of the content contained in these vehicles should be among the topics that should be discussed in other studies.

Differences determined by the social environment dimension and the educational status of the electorate are between the illiterate and the middle school graduates, between the primary school graduates and the graduate / doctoral graduates, between the middle school graduates and the non-literate and master / doctoral graduates, between bachelor / doctoral graduates, between university graduates and master / doctoral graduates and therefore between master and doctoral graduates, primary school, secondary school, high school and university graduates. It has been determined that the level of influence of the voters on voting for the social environment dimension, which comes out from the determined arithmetic mean, shows a slight increase in the other education levels while it is at the lowest level in the graduate / doctorate graduates and even in the middle school graduates.

This suggests that people use their social environment as a source of information as their level of education falls. As a result of these results, it can be said that people with higher education level benefit from communication technology by using the training they have received and they are influencing their voting profits by leading the opinion in the social environment in which they have lower education.

Democratic characteristics of voters are important in the selection of this tool as it is important to determine the means by which TRNC electors' voting decisions can be affected in the process of political campaign studies and to send the messages to be transmitted through the most effective means. It is expected that more effective results will be obtained from the political campaigns that will be carried out by considering the educational levels of voters. Because the difference is that there are differences in the mass media used by individuals with educational levels, and at the same time the opinion leaders in the groups they belong to are also different. It will be useful for the parties and candidates to evaluate voters effectively, especially in the election process, in which voters will be able to determine voting behavior, taking into account their level of involvement and their awareness of the influence processes of voters' close relationships with them. 


\section{REFERENCES}

Akar, E. (2010). Sosyal medya pazarlamasi: Sosyal web de pazarlama stratejileri. Efil Yayınevi.

Akkanat, S. (2015). Kurucu İktidara Dayalı Bir Demokrasinin İmkânı: Siyasal Bir Yaklaşım. Amme Idaresi Dergisi, $48(2)$.

Aziz, A. (2013) Siyasal İletişim. Ankara: Nobel Yayınları.

B Borins, S. (2011). Online Adaydan Online Başkana (Trans. Çetin, N., ed. Devran, Y.) Kampanyalarında Geleneksel Medya, İnternet ve Sosyal Medyanın Kullanımı. İstanbul: Başlık Yayınları, 85-93.

Bat, B. A. V. M. (2009). Siyasal Seçim Kampanyalarında Yeni İletişim Teknolojileri Ve Blog Kullanımı: 2008 Amerika Başkanlık Seçimlerine Yönelik Karşılaştırmalı Bir Analiz. Journal Of Yaşar University, 4(16), 2745-2778.

Blumler, J. G., \& Kavanagh, D. (1999). The third age of political communication: Influences and features. Political communication, 16(3), 209-230.

Burden, B. C. (2009). The dynamic effects of education on voter turnout. Electoral Studies, 28(4), 540-549.

Carpini, M. X. D., \& Keeter, S. (1996). What Americans know about politics and why it matters. London: Yale University Press.

Casper, M. (2001). A definition of "social environment". American Journal of Public Health, 91, 465.

Çobanoğlu, Ş. (2007). Suskunluk sarmalı ve siyasal iletişim. Fide Yayınları.

Dahlgren, P. (2005). The Internet, public spheres, and political communication: Dispersion and deliberation. Political communication, 22(2), 147-162.

Dee, T. S. (2004). Are there civic returns to education? Journal of Public Economics, 88(9), 1697-1720.

Easton, D. (1965). A systems analysis of political life. New Jersey: Wiley.

Ford, P. (1986). Outdoor Education: Definition and Philosophy. New Mexico: ERIC.

Habermas, J. (2006). Political communication in media society: Does democracy still enjoy an epistemic dimension? The impact of normative theory on empirical research. Communication theory, 16(4), 411-426.

Hiebert, R. E. (2005). Commentary: new technologies, public relations, and democracy. Public Relations Review, 31(1), $1-9$.

Highton, B. (2004). Voter registration and turnout in the United States. Perspectives on Politics, 2(3), 507-515.

Kellner, D. (2011). Cultural studies, multiculturalism, and media culture. Gender, race, and class in media: A critical reader, 3, 7-18.

Kılıç, İ., \& Ural, A. (2005). Bilimsel Araştırma Süreci ve SPSS ile Veri Analizi. Ankara: Detay Yayıncılık.

King, R. J., \& Whitehead, M. I. (1986). Assessment of the potency of orally administered progestins in women. Fertility and sterility, 46(6), 1062-1066.

Lewis-Beck, M. S., \& Jacoby, W. G. H., Norpoth, H., \& Weisberg, H. F. (2008). The American Voter Revisited. Ann Arbor, MI: University of Michigan Press.

Luecke, R. (2007). Güç, Etki ve İkna. Berktay (Ed), T. Parlak (Trans.). İstanbul: Türkiye İş.

Mandiberg, M. (Ed.). (2012). The social media reader. New York: NYU Press.

Mayring, P., Gümüş, A., \& Duran, M. S. (2011). Nitel sosyal araştırmaya giriş. Bilgesu.

McLuhan, M. (2001). Gutenberg Galaksisi (trans. Güven Ç.). İstanbul: Yapı Kredi Yayınları, 298-299.

Miller, W. E. (1992). The puzzle transformed: Explaining declining turnout. Political Behavior, 14(1), 1-43.

Miller, W. E., \& Shanks, J. M. (1996). The new American voter (pp. 140-46). Cambridge, MA: Harvard University Press.

Milligan, K., Moretti, E., \& Oreopoulos, P. (2004). Does education improve citizenship? Evidence from the United States and the United Kingdom. Journal of public Economics, 88(9), 1667-1695.

Mutlu, E. (1995). İletişim sözlüğ̈̈̈. İstanbul: Ark Yayınevi.

Nimmo, D. (1970). The Political Persuaders; The Techniques of Modern Election Campaigns.

Oya, T. (2008). Siyasal İletişimi Anlamak. Ankara: İmge Kitabevi Yayınları.

Peker, Ö., \& Aytürk, N. (2000). Etkili yönetim becerileri. Ankara: Yarg1 Yayınevi, 55-61.

Rosenstone, S. J. H., Rosenstone, J. M. J., \& Hansen, J. M. (1993). Mobilization, participation, and democracy in America. UK: Macmillan Publishing Company.

Rosenstone, S. J., \& Wolfinger, R. E. (1980). Who votes. USA: Yale University Press.

Taner, K. A. (1997). Siyaset Bilimi. Ankara: Imge Bookstore. 
Timpone, R. J. (1998). Structure, behavior, and voter turnout in the United States. American Political Science Review, 92(1), 145-158.

Verba, S., Schlozman, K. L., \& Brady, H. E. (1995). Voice and equality: Civic voluntarism in American politics. UK: Harvard University Press.

Windlesham, L. (1966). Communication and Political Power (London: Jonathan Cape) Chapter 6, and Jeremy Moon. European Integration in British Politics, 1950-1963, A Study of Issue Change, 156-207.

Yüksel, A. H., \& Bir, A. A. (2005). İkna ve konuşma. Eskişehir: Anadolu Üniversitesi.

\section{http://www.ejmste.com}

